\title{
EFEK PAPARAN EKSPONENSIAL DAN SQUARE WAVE DALAM METODE ELEKTROPORASI TERHADAP MOTILITAS DAN VIABILITAS SPERMA IKAN NILEM (Osteochilus vittatus)
}

\section{The effect of exponential and square wave exposures in the electroporation method on the motility and viability of bonylip barb (Osteochilus vittatus)}

\author{
Abdul Rahem Faqih ${ }^{1 *}$, Septi Anitasari ${ }^{1}$ dan Angga Wiratama ${ }^{2}$ \\ ${ }^{1}$ Fakultas Perikanan dan Ilmu Kelautan, Universitas Brawijaya, Malang \\ ${ }^{2}$ Praktisi Pembenihan Ikan Nilem \\ *ar.faqih@ub.ac.id
}

\begin{abstract}
Abstrak
Tujuan penelitian ini adalah untuk mengetahui pengaruh perbedaan metode (Square wave and Exponential) terhadap motilitas) dan (viabilitas) sperma ikan nilem (Osteochilus Vittatus). Aspek yang perlu dikaji antara lain penelitian tentang pengaruh medan listrik dengan metode yang berbeda terhadap motilitas dan viabilitas sperma ikan. Penelitian ini dilaksanakan di Laboratorium Breeding (Budidaya Perairan) Fakultas Perikanan dan Ilmu Kelautan serta di Laboratorium Sentral Ilmu Hayati (LSIH) Universitas Brawijaya Malang. Analisa data yang digunakan adalah Uji t karena terdiri dari 2 perlakuan dengan 3 kali ulangan. Sebagai perlakuan adalah metode Square wave dan eksponensial juga dilakukan 2 kontrol yaitu pengamatan sperma sebelum dan sesudah perlakuan. Parameter utama dalam penelitian ini adalah motilitas dan viabilitas sperma ikan nilem. Hasil penelitian menunjukkan bahwa elektroporasi dengan metode Square Wave lebih baik hasilnya jika dibandingkan dengan metode Eksponensial. Hal tersebut dapat dilihat pada nilai rata-rata motilitas sperma ikan nilem dengan menggunakan metode square wave sebesar 34\%, sedangkan dengan metode eksponensial sebesar $11 \%$. Demikian pula hasil nilai rata-rata viabilitas sperma ikan nilem dengan menggunakan metode Square Wave sebesar 56\%, sedangkan dengan menggunakan metode Eksponensial sebesar 25\%. Hasil pengamatan sperma sebelum elektroporasi diperoleh nilai motilitas sebesar $71,3 \%$ dan viiabilitas sebesar $75 \%$, sedangkan sesudah elektroporasi diperoleh nilai motilitas sebesar $46,6 \%$ dan viabilitas sebesar $52,6 \%$.
\end{abstract}

Kata kunci: Elektroporasi, Metode square wave dan exponential wave, Ikan Nilem, Sperma, Motilitas, Viabilitas

\begin{abstract}
The purpose of this study was to determine the effect of different methods (Square wave and Exponential) on the movement (motility) and the ability to live (viability) sperm of bony lip barb (Osteochilus vittatus). For this reason, sperm research used as a medium for inserting foreign DNA into eggs needs to be done. One aspect that needs to be studied includes analysis of the effect of electric fields with different methods on the motility and viability of fish sperm. This research was conducted at the Breeding Laboratory of Aquaculture and Marine Sciences and the Central Laboratory of Life Sciences (LSIH) Universitas Brawijaya Malang. The research method used was experimental, while for data analysis, the t-test was used because it consisted of 2 treatments with three replications. The treatment is a Square wave method and 2 exponential controls, namely sperm observation before and after treatment. The main parameters in this study were the motility and viability of sperm of the barb. The results showed that the electroporation using the Square Wave method was better when compared to the Exponential process. This can be seen in the average sperm motility value of bony lip barb fish using the square wave method by $34 \%$, while the exponential process is $11 \%$. Similarly, the average sperm viability of nilem fish using the Square Wave method is $56 \%$, while the Exponential way by $25 \%$. Sperm observations before electroporation obtained a motility value of $71.3 \%$ and viability of $75 \%$, while after electroporation, the motility value is $46.6 \%$ and viability is $52.6 \%$.
\end{abstract}

Keywords : Electroporation, Square wave and exponential wave method, Barb, Sperm, Motility, Viability

\section{PENDAHULUAN}

Elektroporasi merupakan proses penerapan medan listrik (pulsa) terhadap sel hidup dalam jangka waktu yang singkat. Elektroporasi memungkinkan pembentukan pori-pori sehingga molekul eksogen seperti DNA dapat masuk ke dalam sel. Elektroporasi merupakan teknik yang sangat efisien untuk memasukkan asam nukleat, protein, karbohidrat, pewarna, 
partikel virus dan molekul lain ke dalam berbagai macam sel seperti prokariotik dan eukariotik (Chen et al., 1994).

Metode elektroporasi menggunakan serangkaian listrik arus pendek untuk melemahkan membran sel guna membantu DNA rekombinan masuk ke dalam sel tertentu. Pada umumnya metode elektroporasi digunakan untuk transfer gen pada bakteri yeast, tanaman dan sel-sel hewan (Chen et al., 1994). Menurut Weaver (1993), perubahan permeabilitas sel oleh suatu medan elektrik disebut elektroporasi. Elektroporasi telah digunakan untuk memindahkan makromolekul seperti DNA dan protein ke dalam sel tumbuhan, sel hewan dan sel bakteri.

Metode elektroporasi yang umum digunakan untuk menghasilkan kondisi yang optimal terbukti memakan waktu. Dengan diperkenalkannya sistem elektroporasi "Gene Pulser", kondisi optimal dapat ditentukan dengan cepat. Gene Pulser adalah sistem elektroporasi modular, yang mencakup unit utama, memiliki 2 modul aksesori (modul CE dan modul PC). Modul CE digunakan untuk media yang memiliki hambatan rendah $(<1000 \mathrm{Ohm})$ dan tegangan yang rendah. Pada tegangan eksponensial, modul CE berfungsi mengontrol kapasitan selama bertambahnya lama kejutan yang konstan atau stabil. Sedangkan tegangan Square wave memberikan kebutuhan kapasitan yang besar $(3.275$ F) untuk mengirim kejutan square wave dalam media yang memiliki hambatan rendah.

Modul PC dibutuhkan untuk elektroporasi tegangan tinggi. Modul PC digunakan untuk hambatan $50 \mathrm{ohm}-1000$ ohm dalam setiap kenaikan $50 \mathrm{ohm}$. Modul ini efektif untuk mengontrol konstannya waktu ketika digunakan hambatan tinggi, akan tetapi memiliki efek yang sedikit pada pengontrolan konstannya waktu ketika digunakan pada hambatan rendah.

Modul CE digunakan untuk elektroporasi sel eukariotik, termasuk sel mamalia dan protoplasma tanaman. Sedangkan modul PC digunakan untuk elektroporasi bakteri dan jamur serta aplikasi lain dimana kejutan tegangan tinggi diterapkan pada sampel volume kecil dan ketahanan tinggi. Sistem Gene Pulser menghasilkan bentuk gelombang eksponensial dan persegi (square), memungkinkan untuk memilih gelombang yang terbaik untuk proses elektroporasi. Baik secara eksponensial maupun square telah digunakan dengan sangat efektif untuk elektroporasi. Bentuk gelombang elektroporasi dapat memiliki dampak yang signifikan terhadap efisiensi transformasi untuk tipe sel yang berbeda (Chen et al., 1994).

Transfer gen pada ikan dengan menggunakan metode elektroporasi dengan sperma ikan sebagai media transfer gen masih belum dilakukan di Indonesia. Padahal Kang et al. (1999) menyatakan bahwa sel sperma dapat digunakan sebagai media untuk memasukkan DNA asing ke dalam sel telur. Oleh karena itu perlu dilakukan penelitian tentang pengaruh metode elektroporasi yang berbeda terhadap motilitas dan viabilitas sperma ikan.

Perpindahan molekul DNA ke dalam sel, suatu transfer gen dari sel yang berisi DNA asing melalui kejutan listrik. Dua jenis kejutan listrik yang berbeda yaitu Square wave dan Exponential wave telah digunakan dalam mentransfer gen ke dalam sperma ikan. Tegangan dari Square wave lebih diarahkan kepada amplitudo yang diperlukan yang mana untuk menjaga lamanya waktu kejutan, kemudian dikembalikan ke nol. Sedangkan Exponential wave, tegangan ditujukan untuk suatu amplitudo yang diinginkan, kemudian memberikan kerusakan yang bersifat eksponen atau berkelanjutan. Amplitudo itu sendiri adalah jarak terjauh simpangan dari titik keseimbangan, akan tetapi dalam gelombang ini amplitudo tergantung pada tegangan yang diberikan (Müller et al., 1992).

Sperma adalah sel-sel spermatozoa yang berada dalam larutan seminal dan dihasilkan oleh hidrasi testis, atau salah satu 
bagian dari alat reproduksi ikan (Wijayanti dan Simanjuntak, 2006). Spermatozoa merupakan sel padat dan sangat khas, tidak tumbuh atau membagi diri serta tidak mempunyai peranan fisiologis apapun pada hewan yang menghasilkannya, semata-mata hanya untuk membuahi telur pada jenis yang sama (Susilawati, 2011).

Media transfer gen, sperma sangat potensi dikembangkan dalam transgenik ikan karena prosedurnya yang relatif alami dan lebih efisien (Sin et al., 2000). Kemudian Lavitrano et al. (2005) menyatakan sperma memiliki kelebihan sebagai media transfer gen, karena dalam proses transfer materi genetik, sperma sebagai vektor yang relatif alami. Sel sperma telah digunakan sebagai vektor transfer gen pada ikan mas, lele dan nila (Müller et al., 1992). Tujuan penelitian ini adalah untuk mengetahui pengaruh kejutan listrik dengan metode yang berbeda (Square wave dan Eksponensial) terhadap pergerakan (motilitas) dan kemampuan hidup (viabilitas) sperma ikan nilem (Osteochilus hasselti).

\section{METODOLOGI}

\section{Waktu dan Tempat}

Penelitian ini dilaksanakan di Laboratorium Breeding (Budidaya Perairan) Fakultas Perikanan dan Ilmu Kelautan serta di Laboratorium Sentral Ilmu Hayati (LSIH) Universitas Brawijaya Malang.

\section{Materi Penelitian}

Pada penelitian ini bahan dan alat yang digunakan antara lain meliputi induk jantan ikan Nilem (Osteochilus hasselti), larutan $\mathrm{NaCl}$ fisiologis, pewarna Eosinnigrosin, sperma ikan Nilem, akuades, ovaprim, air, es Batu, satu set alat elektroporator (BIO-RAD), cuvette, mikroskop, kolam pemeliharaan induk ikan, bak plastik, object glass, cover glass, pipet volume, mikro pipet, tisu, spuit, blower, dan hand tally counter.

\section{Rancangan Penelitian}

Penelitian ini menggunakan dua perlakuan yang masing-masing perlakuannya diulang sebanyak tiga kali dan kontrol diberikan pada semua perlakuan yang fungsinya untuk membandingkan dengan perlakuan.

Penelitian ini, perlakuan yang digunakan adalah penggunaan metode yang berbeda pada pemberian kejutan listrik dengan kuat medan listrik $40 \mathrm{~V} / \mathrm{Cm}$, yaitu A (pemberian kejutan listrik dengan metode Square Wave menggunakan parameter ukur tegangan $40 \mathrm{~V} / \mathrm{cm}$ ) dan $\mathrm{B}$ (pemberian kejutan listrik dengan metode Eksponensial menggunakan parameter ukur tegangan 40 $\mathrm{V} / \mathrm{cm})$. Untuk membedakan atau membandingkan dua macam perlakuan umumnya dilakukan dengan uji $\mathrm{t}$ (t-test). Pada prinsipnya berbeda atau tidaknya dua macam perlakuan tersebut dapat diketahui dari perbandingan t hitung (calculated) dan t daftar. Oleh karena itu, sebaiknya dilihat kembali tentang uji $\mathrm{t}$ dan sebaran nilai $\mathrm{t}$ (Sastrosupadi, 2000).

\section{Prosedur Kerja \\ Setting Alat Elektroporasi}

Kejutan listrik (V/cm) pada sperma ikan nilem pertama menyiapkan alat elektroporasi dengan langkah-langkah sebagai berikut : steker alat disambungkan ke sumber listrik yang sesuai, tombol "POWER" di samping kanan alat ditekan untuk menyalakan alat. Tampilan awal yaitu "HOME SCREEN" akan muncul .Pada tampilan "HOME SCREEN" dipilih no. 3 atau menggunakan panah ke atas atau ke bawah untuk memilih "Square wave protocol/Eksponensial protocoli', 5).

Kemudian muncul tampilan detail metode Square wave/Exponential protocol, selanjutnya masukan beberapa parameter yang ditentukan seperti : Lama kejutan + besar kuat medan $(\mathrm{V} / \mathrm{cm})$, Lama kejutan + besar kuat medan + jumlah kejutan + interval tegangan. Setelah itu sisiapkan cuvette yang akan dipakai yaitu cuvette ukuran $0,2 \mathrm{~cm}$. Setelah parameter yang dimasukkan sesuai maka disimpan dan 
diberi tanda dengan abjad, agar saat memberikan pulse dapat dilakukan dengan cepat, 8). Kuat medan yang dimasukkan 40 $\mathrm{V} / \mathrm{cm}$,.Lama kejutan yang digunakan yaitu $0,5 \mathrm{~ms}$.

\section{Persiapan Sperma}

Persiapan sampel dengan langkah sebagai berikut: $25 \mathrm{ml}$ sperma dimasukkan ke dalam cuvette menggunakan mikro pipet setelah itu cuvette ditutup dengan rapat. Tutup shock pod dibuka. Cuvette berisi sampel dipasang pada shock pod kemudian shock pod ditutup kembali. Sperma siap untuk diberi kejutan.

Setelah itu besar kuat medan yang diberikan dipilih dengan memilih tanda, kemudian "enter" ditekan sehingga tampilan tegangan terbuka, tombol "PULSE" ditekan untuk memulai pemberian kejutan pada sampel. Akan muncul tampilan yaitu hasil perlakuan yang diberikan pada sampel.

Dicatat hasil dari penurunan tegangan yang muncul di layar alat elektroporator. Setelah sperma diberi kejutan listrik kemudian $25 \mathrm{jl}$ sperma yang ada di dalam cuvette ditambahkan larutan $\mathrm{Na}$ Fisiologis sebanyak 275 jl. Selanjutnya sperma hasil elektroporasi diamati motilitas dan viabilitasnya dan dilanjutkan analisa statistiknya.

\section{Analisis Data}

Analisa data yang digunakan adalah Uji t karena terdiri dari 2 perlakuan dengan 3 kali ulangan. Sebagai perlakuan adalah metode Square wave dan eksponensial juga dilakukan 2 kontrol yaitu pengamatan sperma sebelum dan sesudah perlakuan.

\section{HASIL DAN PEMBAHASAN Kualitas Sperma Kontrol}

Sperma yang digunakan pada penelitian ini mempunyai kualitas baik. Hal tersebut terlihat dari motilitas dan viabilitas spermanya. Selama berlangsungnya penelitian, motilitas sperma yang didapat adalah sebesar $71,3 \%$ dan viabilitas yang didapat adalah sebesar $75 \%$. Cara pengambilan sperma induk nilem jantan yaitu melakukan stripping pada ikan tersebut.

\section{Motilitas Spermatozoa}

Motilitas sperma kontrol sebelum elektroporasi (rata-rata 71,3\%) lebih besar dibandingkan dengan motilitas sperma kontrol sesudah elektroporasi (rata-rata 46,6\%). Hal ini disebabkan karena sperma kontrol sebelum elektroporasi masih segar dan baik, sedangkan sperma kontrol sesudah elektroporasi pengamatan dilakukan setelah perlakuan elektroporasi, sehingga kualitas sperma sudah dipengaruhi oleh jeda waktu perlakuan. Sehingga pengamatan motilitas kontrol sesudah elektroporasi baru diamati setelah sperma diberi perlakuan.

Artinya sperma kontrol sebelum dan sesudah adalah sperma murni tanpa perlakuan kejutan listrik. Waktu atau jeda saat perlakuan dapat dilihat pada Tabel 1 berikut ini.

Tabel 1. Waktu pemberian perlakuan kejutan listrik.

\begin{tabular}{ccccc}
\hline Perlakuan & \multicolumn{3}{c}{ Waktu Perlakuan (WIB) } & Rata-Rata (menit) \\
& 1 & 2 & 3 & \\
\hline Kontrol Sebelum & $08: 05$ & $08: 10$ & $08: 14$ & 3 \\
Square Wave & $08: 21$ & $08: 25$ & $08: 29$ & 2,66 \\
Eksponensial Wave & $08: 40$ & $08: 46$ & $08: 52$ & 6 \\
Kontrol Sesudah & $09: 04$ & $09: 11$ & $09: 20$ & 5,33 \\
\hline
\end{tabular}

Tabel di atas diketahui jeda saat pemberian perlakuan adalah 1 jam 15 menit, sehingga kualitas sperma kontrol sesudah menjadi menurun karena dibiarkan sampai 1 jam 15 menit. Hasil persentase motilitas sperma ikan nilem dapat dilihat pada Tabel 2 berikut. 
Tabel 2. Data nilai motilitas sperma ikan nilem (\%).

\begin{tabular}{cccccc}
\hline Perlakuan & \multicolumn{3}{c}{ Ulangan } & Total & Rata-rata \\
& 1 & 2 & 3 & & \\
\hline Square Wave & 35 & 35 & 32 & 102 & 34 \\
Eksponensial Wave & 15 & 10 & 8 & 33 & 11 \\
K. Sebelum Square Wave & 75 & 74 & 65 & 214 & 71,3 \\
K. Sesudah Square Wave & 50 & 45 & 45 & 140 & 46,6 \\
\hline
\end{tabular}

Diagram tersebut terlihat bahwa nilai rata-rata persentase motilitas perlakuan lebih rendah dibandingkan dengan kontrol, dengan nilai rata-rata $34 \%$ untuk square wave, $11 \%$ untuk eksponensial dan $71,3 \%$ untuk kontrol sebelum dan $46,6 \%$ untuk kontrol sesudah.

Adanya perbedaan nilai rata-rata motilitas sperma kontrol dengan perlakuan disebabkan karena pada kontrol sperma tidak diberi perlakuan apapun, berbeda dengan perlakuan square dan eksponensial wave yang masing-masing sperma diberi perlakuan kejutan listrik 40 volt. Menurut Hadie et al. (2016), kejutan listrik akan berpengaruh terhadap produksi spermatozoa, sperma yang dikeluarkan dari testis bisa menjadi cacat dan dapat menurunkan tingkat motilitas spermatozoa serta dapat meningkatkan nilai mortalitas dan abnormalitas pada spermatozoa.

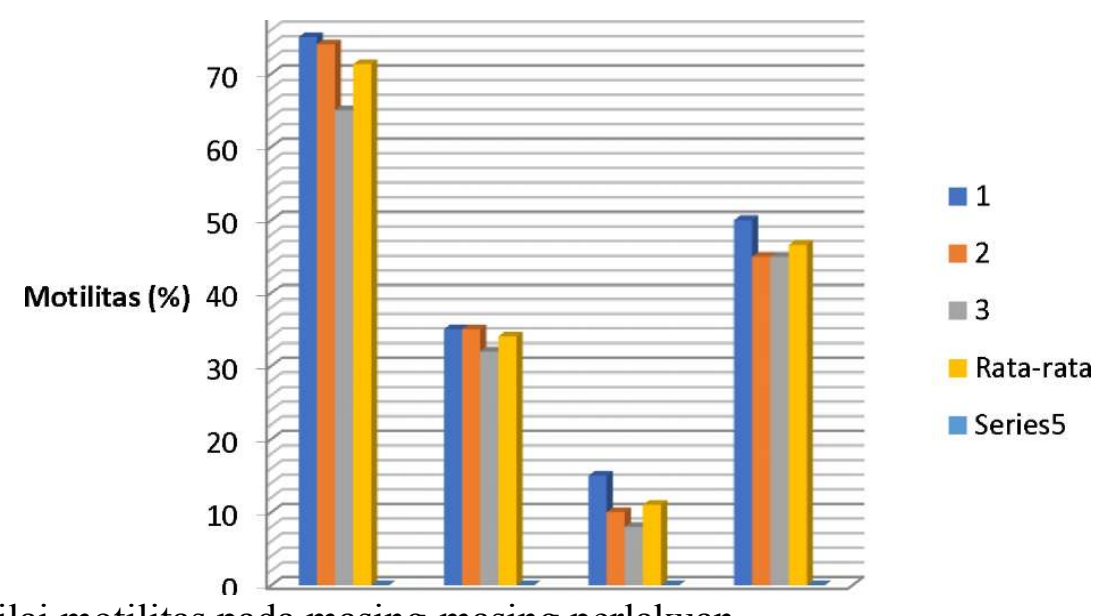

Gambar 1. Nilai motilitas pada masing-masing perlakuan.

Kualitas sperma dengan tingkat motilitas $60 \%$ dapat dikatakan bagus karena menurut Tabares et al. (2007), pada penelitiannya menggunakan ikan Brycon henni (ikan air tawar) menunjukkan bahwa pada sperma kontrol memiliki tingkat motilitas $78 \%$ karena di dalam cairan seminal plasma terdapat ion yang lengkap seperti $\mathrm{KCl}, \mathrm{NaCl}, \mathrm{CaCl}_{2}$, dan $\mathrm{MgCl}_{2}$. Fungsi cairan seminal antara lain mengembangkan kapasitas sperma dalam bergerak (Mochida et al., 1999; Ohta dan Unuma, 2003) dan mempertahankan motilitas sperma saat bergerak dalam air (Morisawa dan Suzuki, 1980; Scott dan Baynes ,1980).
Menurut pendapat Toelihere (1981), persentase motilitas spermatozoa di bawah $40 \%$, menunjukkan nilai motilitas spermatozoa yang kurang baik dalam proses pembuahan telur atau sering berhubungan dengan infertilitas. Hasil perhitungan didapatkan hasil t hitung $(9,89)$ lebih besar dari t tabel 1\% (4,604), yang berarti metode memberikan pengaruh sangat nyata terhadap motilitas sperma atau dapat disimpulkan menerima $\mathrm{H} 1$ dan menolak H0.

\section{Viabilitas Spermatozoa}

Pengamatan Viabilitas atau daya tahan hidup spermazoa pada penelitian ini 
dilakukan dengan menggunakan bahan pewarna eosin-nigrosin, kemudian diamati viabilitasnya di bawah mikroskop. Zat pewarna ini akan diserap oleh sel spermatozoa yang mati, sedangkan spermatozoa yang hidup tidak terwarnai atau sedikit sekali menyerap zat warna tersebut.

Hal ini sesuai dengan pendapat Toelihere (1981) yang menyebutkan bahwa pada saat spermatozoa dicampur dengan zat warna, spermatozoa yang hidup tidak menyerap zat warna atau sedikit sekali menyerap zat warna. Sedangkan spermatozoa yang mati akan menyerap zat warna dalam jumlah yang sangat banyak, karena permeabilitas dinding sel spermatozoa akan meninggi setelah mati.

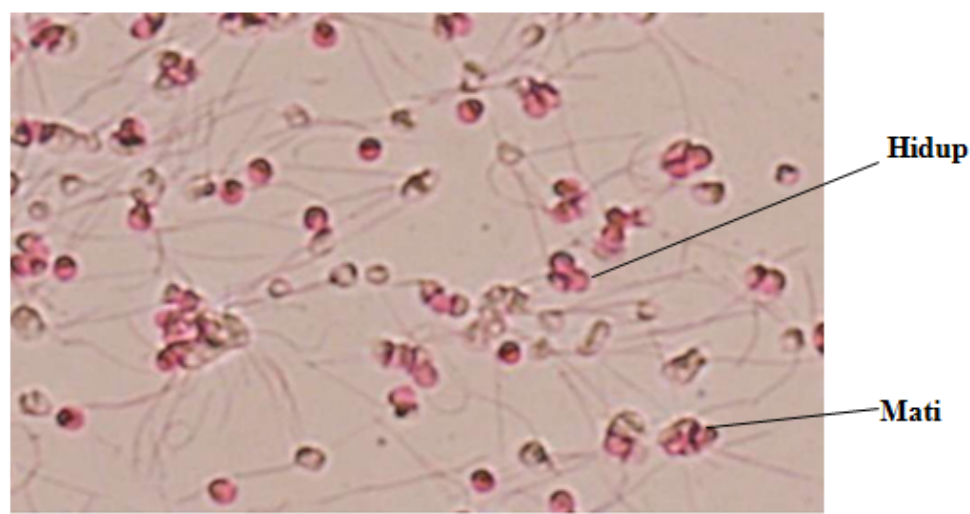

Gambar 2. Gambar sperma (sperma yang hidup warna bening dan yang mati warna gelap atau merah) pada metode Square Wave (pembesaran 400x).

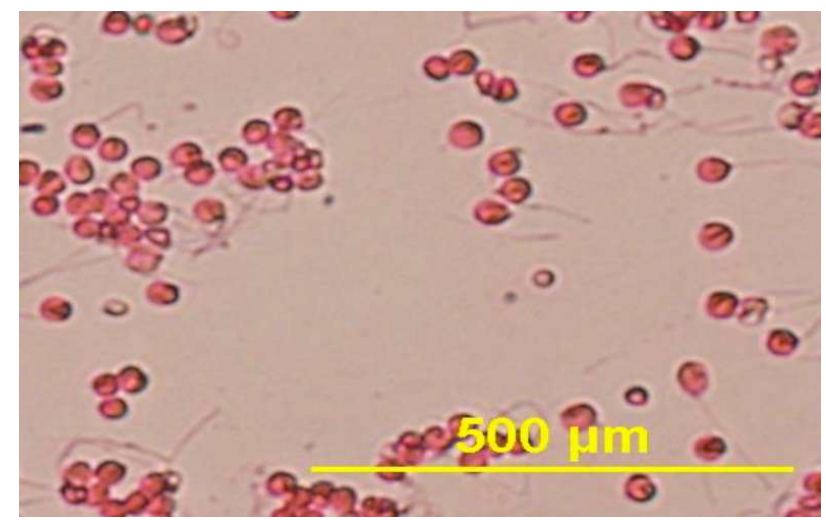

Gambar 3. Gambar sperma (sperma yang hidup, warna bening dan yang mati) warna merah muda pada metode Eksponensial wave (pembesaran 400x).

Hasil pengamatan nilai viabilitas spermatozoa dapat dilihat pada tabel 3 . Diagram tersebut terlihat bahwa rata-rata persentase viabilitas perlakuan lebih rendah dari pada rata-rata persentase viabilitas kontrol. Sperma kontrol tidak diberi perlakuan apapun, sedangkan sperma square dan eksponensial diberi perlakuan kejutan listrik 40 volt. Inilah yang menyebabkan rata-rata persentase motilitas sperma kontrol lebih tinggi.
Nilai persentase rata-rata motilitas sperma kontrol sebelum 75\%, kontrol sesudah $52,6 \%$, square wave $56 \%$, dan eksponensial wave $25 \%$. Menurut Weaver (1993), tegangan yang diberikan terhadap sperma menyebabkan terbukanya pori-pori sel membran, akan tetapi dapat juga sel rusak atau pecah yang mengakibatkan sel tersebut mati. Hasil perhitungan didapatkan hasil $t$ hitung $(8,68)$ lebih besar dari $t$ tabel $1 \% \quad(4,604)$ yang berarti metode berpengaruh sangat nyata terhadap 
viabilitas sperma atau dapat disimpulkan menerima H1 dan menolak H0.

Tabel 3. Data nilai viabilitas spermatozoa (\%).

\begin{tabular}{cccccc}
\hline Perlakuan & \multicolumn{3}{c}{ Ulangan } & Total & Rata-rata \\
& 1 & 2 & 3 & & \\
\hline Square Wave & 60 & 55 & 53 & 168 & 56 \\
Eksponensial Wave & 30 & 25 & 20 & 75 & 25 \\
K. Sebelum & 78 & 75 & 72 & 225 & 75 \\
K. Sesudah & 55 & 53 & 50 & 158 & 52,6 \\
\hline
\end{tabular}

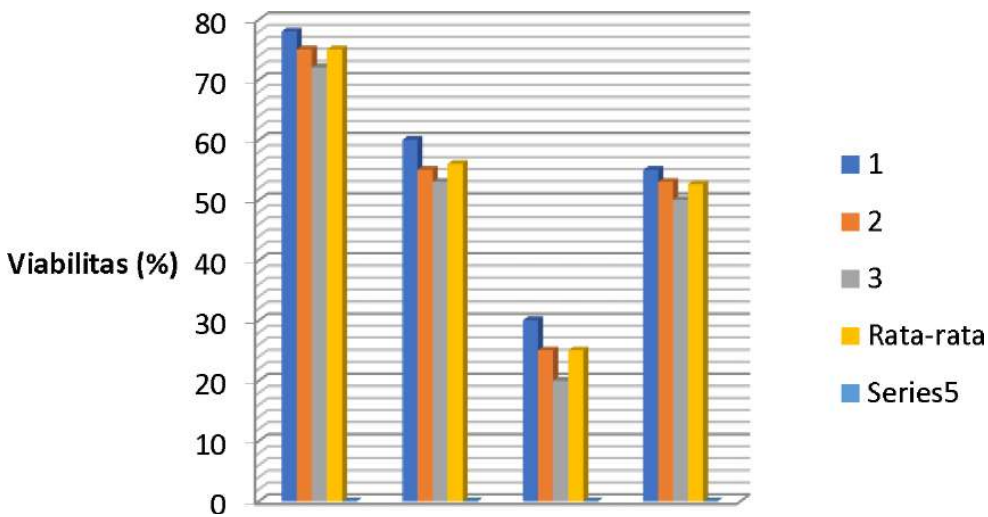

Gambar 4. Nilai viabilitas pada masing-masing perlakuan.

\section{Kualitas Sperma Elektroporasi}

Volume sperma yang diberi kejutan adalah sebesar $25 \mu 1$, kemudian dimasukkan ke dalam cuvette tipe $0,2 \mathrm{~mm}$, lalu diberi perlakuan kejutan listrik. Setelah sperma diberi kejutan listrik, sperma ditambahkan larutan $\mathrm{NaCl}$ fisiologis sebanyak $275 \mu \mathrm{l}$ agar kondisi sperma relatif stabil serta agar dalam pengambilan sperma lebih mudah. Sperma yang keluar dari tubuh ikan tidak akan bertahan lama, karena kondisinya berubah.

Oleh karena itu sperma yang telah ditampung diusahakan mempunyai kondisi yang dapat mendukung kehidupannya. Salah satu cara untuk tetap menjaga kualitas sperma adalah dengan melakukan penambahan larutan fisiologis $(\mathrm{NaCl}$ fisiologis). Menurut Hidayaturrahmah (2007) penggunaan larutan fisiologis yang mengandung $\mathrm{NaCl}$ dan urea dapat mempertahankan daya hidup spermatozoa antara 20-25 menit.

\section{Metode Square Wave}

Elektroporasi sperma dengan menggunakan metode Square Wave merupakan salah satu metode elektroporasi yang tegangannya lebih diarahkan kepada amplitudo yang diperlukan untuk menjaga lamanya waktu kejutan (Sin et al., 2000).

Penelitian diperoleh hasil rata-rata nilai motilitas sperma ikan nilem setelah diberi perlakuan kejutan listrik dengan tegangan 40 volt dan lama tegangan $0,5 \mathrm{~ms}$ menggunakan metode Square Wave adalah sebesar 34\%. Nilai motilitas ini lebih kecil bila dibandingkan dengan nilai sperma kontrol sebelum diberi perlakuan kejutan listrik yaitu sebesar 71,3\%. Penurunan motilitas ini dapat diakibatkan karena terjadinya adaptasi antara spermatozoa dengan tegangan sehingga mengakibatkan terjadinya gangguan terhadap permeabilitas membran atau selaput sperma, menurunkan aktivitas metabolisme, kerusakan sel dan penurunan motilitas.

Hal ini sesuai dengan pendapat Jeyendran et al. (1984) yang menyatakan bahwa permeabilitas membran spermatozoa erat kaitannya dengan motilitas dan viabilitas spermatozoa karena seperti yang diketahui permeabilitas membran sangat berkaitan dengan transportasi nutrisi yang 
penting peranannya dalam metabolisme sel. Ditambahkan oleh Tsai et al. (1997) yang menyatakan bahwa motilitas sperma yang diperoleh sangat tergantung pada level tegangan selama elektroporasi.

Nilai viabilitas sperma ikan nilem setelah diberi kejutan dengan menggunakan metode yang sama diperoleh rata-rata sebesar 56\%. Nilai ini juga lebih kecil bila dibandingkan dengan rata-rata nilai viabilitas sperma kontrol sebelum diberi perlakuan yaitu sebesar $75 \%$. Adanya penurunan nilai viabilitas sperma ini dapat disebabkan karena pemberian kejutan listrik dengan tegangan tinggi yang dapat menyebabkan rusaknya membran plasma dan penurunan motilitas sperma. Sedangkan untuk kontrol sesudah elektroporasi diamati untuk membandingkan antara nilai viabilitas sperma sebelum dielektroporasi dan sesudah dielektroporasi.

Maxwell dan Johnson (1999) menyatakan bahwa kerusakan membran spermatozoa akan berdampak pada membran yang pada awalnya mempunyai sifat permeabel, tidak lagi mampu menyeleksi keluar masuknya zat, yang akhirnya pada saat dilakukan uji warna eosin-nigrosin zat tersebut bisa masuk ke dalam plasma. Ditambahkan oleh Tang dan Affandi (2001) bahwa permukaan spermatozoa dibungkus oleh suatu membran lipoprotein. Apabila spermatozoa tersebut mati maka permeabilitas membrannya meninggi, terutama di daerah pangkal kepala dan hal ini merupakan dasar pewarnaan sperma yang membedakan spermatozoa yang hidup dengan spermatozoa yang mati.

\section{Metode Eksponensial Wave}

Elektroporasi sperma dengan metode Eksponensial Wave merupakan salah satu metode elektroporasi dengan menaikkan voltase sampai pada amplitudo yang diinginkan kemudian menurun secara eksponensial (Sin et al., 2000). Berarti dalam hal ini faktor yang berpengaruh terhadap metode Eksponensial adalah tegangan, waktu dan kekuatan bidang. Eksponensial wave, tegangan ditujukan untuk suatu amplitudo yang diinginkan, kemudian memberikan kerusakan yang bersifat eksponen. Pada metode ini panjang kejutan memiliki nilai yang sama dengan lama kejutan.

Penelitian diperoleh hasil rata-rata nilai motilitas sperma ikan nilem setelah diberi perlakuan kejutan listrik dengan tegangan 40 volt menggunakan metode Eksponensial Wave adalah sebesar 11\%. Nilai persentase motilitas ini jauh lebih kecil bila dibandingkan dengan nilai sperma kontrol sebelum diberi perlakuan kejutan listrik sebesar 71,3\%. Begitu juga dengan nilai rata- rata viabilitasnya yaitu sebesar $25 \%$, juga jauh lebih rendah dibandingkan dengan rata-rata persentase sperma kontrol sebelum diberi kejutan listrik sebesar $75 \%$ dengan metode eksponensial.

Sedangkan untuk kontrol sesudah elektroporasi dilakukan untuk membandingkan antara nilai viabilitas sperma sebelum dielektroporasi dan sesudah dielektroporasi. Menurut Nakamura et al. (2009), penggunaan tegangan listrik tinggi yang diberikan pada sampel dapat menyebabkan produksi panas oleh generator yang bisa membunuh sebagian besar sampel yang dielektroporasi.

\section{Perbandingan Hasil Metode Square Wave dan Eksponensial Wave}

Hasil yang didapat dari perlakuan pemberian kejutan menggunakan dua metode elektroporasi yang berbeda diperoleh rata-rata nilai motilitas dan viabilitas dari penggunaan metode Square Wave ternyata lebih besar daripada nilai motilitas dan viabilitas dari penggunaan metode Eksponensial Wave. Hal ini kemungkinan karena kerusakan sel spermatozoa pada metode Square Wave lebih kecil dibanding dengan metode Eksponensial. Chen et al (1994) menyatakan bahwa metode Square dapat menghasilkan tegangan yang besar sehingga efisiensi pemasukan DNA asing lebih besar karena pembukaan pori relatif 
lebih besar, namun gelombangnya (pulse length) sangat pendek sehingga mencegah sel rusak dan dapat kembali seperti semula karena panas yang ditimbulkan relatif kecil.

Sehingga dapat dikatakan Metode Square Wave dapat menghantarkan tegangan tinggi dalam gelombang yang pendek sehingga menimbulkan sedikit panas, sehingga transfer DNA dapat terjadi tanpa membunuh sel atau embrio. Hal ini juga sesuai dengan pendapat Saunders et al. (1989) bahwa penggunaan dua metode dalam elektroporasi (Square/Eksponensial Wave) akan menimbulkan efek pada suatu sel, akan tetapi pada penggunaan metode Square Wave memiliki persentase bertahan hidup yang lebih besar pada sel yang dielektroporasi.

Metode Square Wave dicirikan dengan tegangan (voltase), panjang kejutan (pulse length), jumlah kejutan (number of pulse) dan jarak antara kejutan (pulse interval). Sedangkan pada metode Eksponensial Wave dicirikan dengan tegangan (voltase), lama kejutan (TC) dan hambatan (resistence). Dari perlakuan elektroporasi dengan menggunakan tegangan 40 volt pada metode Square Wave menghasilkan tegangan akhir 37 volt, panjang gelombang $0,5 \mathrm{~ms}$, jumlah kejutan adalah 1 (satu). Selanjutnya pada metode Eksponensial menghasilkan tegangan akhir 37 volt dan waktu konstan (TC) 10,4 ms. Berdasarkan hasil tersebut diketahui bahwa lama kejutan atau panjang kejutan (pulse length) metode Eksponensial Wave lebih lama daripada Metode Square Wave, sehingga metode Eksponensial menghasilkan panas yang lebih besar yang mengakibatkan rusaknya sel spermatozoa.

Kedua metode tersebut dapat diketahui bahwa penggunaan metode Square Wave lebih baik dari pada Metode Eksponensial Wave. Hasil ini terlihat dari nilai motilitas dan viabilitas sperma ikan nilem yang lebih tinggi dibandingkan dengan metode Eksponensial.

\section{KESIMPULAN DAN SARAN Kesimpulan}

Hasil penelitian ini dapat diperoleh kesimpulan bahwa kondisi sperma kontrol sebelum dilakukan elektroporasi lebih baik dibandingkan kondisi sperma kontrol setelah dilakukan elektroporasi.

Pemberian kejutan listrik dengan metode yang berbeda berpengaruh sangat nyata terhadap motilitas dan viabilitas sperma ikan nilem (Osteochilus hasselti). Lama kejutan atau panjang kejutan (pulse length) metode Eksponensial Wave lebih besar daripada Metode Square Wave, sehingga metode Eksponensial menghasilkan panas yang lebih besar yang mengakibatkan rusaknya sel spermatozoa.

\section{Saran}

Hasil penelitian dapat disarankan sebagai berikut: Sebaiknya elektroporasi menggunakan metode Square Wave agar diperoleh nilai motilitas dan viabilitas sperma yang tinggi.

Perlu dilakukan penelitian lebih lanjut tentang elektroporasi dengan metode Square Wave pada sel telur ikan.

\section{DAFTAR PUSTAKA}

Chen, T.T., Marsh, A., Shamblott, M., Chan, K.M., Tang, Y.L., Cheng, C.M. dan Yang, B.Y., 1994. 6 structure and evolution of fish growth hormone and insulinlike growth factor genes, Fish Physiology, 13, pp 179 - 209.

Hadie, W., Kusrini, E., Priyadi, A. dan Alimuddin, A., 2016. Penyisipan gen warna pada ikan mas koki Carassius auratus menggunakan metode elektroforasi dalam upaya meningkatkan kualitas ikan hias. Jurnal Riset Akuakultur, 5(3), pp.335343.

Hidayaturrahmah, 2007. Waktu Motilitas dan Viabilitas Spermatozoa Ikan Mas (Cyprinus carpio L.) Pada Beberapa Konsentrasi Larutan Fruktosa. BIOSCIENTIAE, 4(1), pp.9 - 18.

Jeyendran, R.S., Van der Ven, H.H., PerezPelaez, M., Crabo, B.G. dan 
Zaneveld, L.J.D., 1984. Development of an assay to assess the functional integrity of the human sperm membrane and its relationship to other semen characteristics. Reproduction, 70(1), pp.219-228.

Kang, J.H., Yoshizaki, G., Homma, O., Strusmann, C.A. dan Takashima, F., 1999. Effect of an osmotic differential on the efficiency of gene transfer by electroporation of fish spermatozoa, Aquaculture, 173(1-4), pp. 297 - 307.

Lavitrano, M., Busnelli, M., Cerrito, M. G., Giovannoni, R., Manzini, S. dan Vargiolu, A., 2005. Sperm-Mediated Gene Transfer, Reproduction, Fertility and Development, 18(2), pp. 19-23.

Maxwell, W.M.C. and Johnson, L.A., 1999. Physiology of spermatozoa at high dilution rates: the influence of seminal plasma. Theriogenology, 52(8), pp.1353-1362.

Mochida, K., Kondo, T., Matsubara, T., Adachi, S. dan Yamauchi, K., 1999. A high molecular weight glycoprotein in seminal plasma is a sperm immobilizing factor in the teleost Nile tilapia, Oreochromis niloticus. Development, growth \& differentiation, 41(5), pp.619-627.

Morisawa, M. dan Suzuki, K., 1980. Osmolality and potassium ion: their roles in initiation of sperm motility in teleosts. Science, 210(4474), pp.1145-1147.

Müller, F., Ivics, Z., Erdelyi, F., Papp, T., Varadi, L., Horvath, L., Maclean, N. and Orban, L., 1992. Introducing foreign genes into fish eggs with electroporated sperm as a carrier. Molecular marine biology and biotechnology, 1(4/5), pp.276-281.

Nakamura, K., Shimabukuro, R., Fujiwara, Y., Akiyama, T., Ito, T. dan Freeman, A.J., 2009. Giant modification of the magnetocrystalline anisotropy in transition-metal monolayers by an external electric field. Physical review letters, 102(18), p.187201.
Ohta H. dan Unuma T., 2003. Induction of Sperm Maturation. In: Aida K., Tsukamoto K., Yamauchi K. (eds) Eel Biology (pp.415-423). Springer, Tokyo.

Sastrosupadi, A., 2000. Rancangan percobaan praktis bidang pertanian. Kanisius. Yogyakarta. p.276.

Saunders, J.A., Smith, C.R. dan Kaper, J.M., 1989. Effects of Electroporation Pulse Wave on th e Incorporation of Viral RNA into Tobacco Protoplasts. BioTechniques 7(10), pp.1124-1131.

Scott, A.P. dan Baynes, S.M., 1980. A review of the biology, handling and storage of salmonid spermatozoa. Journal of Fish Biology, 17(6), pp.707-739.

Sin, F.Y.T., Walker, S.P., Symonds, J.E., Mukherjee, U.K., Khoo, J.G.I. dan Sin, I.L., 2000. Electroporation of salmon sperm for gene transfer: Efficiency, reliability, and fate of transgene, Molecular Reproduction and Development, 56(S2), pp. 285288.

Susilawati, T., 2011. Spermatology. Universitas Brawijaya Press.

Tabares, J., Ruiz, T., Arboleda, L. dan Olivera, M., 2007. Effect of some ions on sperm activation in Brycon henni (Eigenmann 1913). Colombian Biological Act, 12(1), pp. 87-98.

Tang, U.M. and Affandi, R., 2001. Biologi reproduksi ikan. Pusat Penelitian Kawasan Pantai dan Perairan Universitas Riau, Riau.

Toelihere, M.R., 1981. Fisiologi reproduksi pada ternak. Penerbit Angkasa. Bandung.

Tsai, H.J., Lai, C.H. and Yang, H.S., 1997. Sperm as a carrier to introduce an exogenous DNA fragment into the oocyte of Japanese abalone (Haliotis divorsicolor suportexta). Transgenic research, 6(1), pp.85-95.

Weaver, J.C., 1993. Electroporation: a General Phenomenon For Manipulating Cells and Tissues. $J$. Cell Biochem, 51(4), pp. 426435. 
Wijayanti, G.E. dan Simanjuntak, S.B., 2006. Viabilitas sperma Ikan Nilem (Osteochilus hasselti CV) setelah penyimpanan jangka pendek dalam larutan ringer. Jurnal Perikanan Universitas Gadjah Mada, 8(2), pp.207-214. 